\title{
Conformational Analysis of Cyclolinopeptide A, a Cyclic Nonapeptide: Nuclear Overhauser Effect and Energy Minimization Studies
}

\author{
S. RAGHOTHAMA, Sophisticated Instruments Facility, Indian \\ Institute of Science, Bangalore 560 012; C. RAMAKRISHNAN, \\ Molecular Biophysics Unit, Indian Institute of Science, Bangalore 560 \\ 012; D. BALASUBRAMANIAN, Centre for Cellular and Molecular \\ Biology, Hyderabad 500 007; and P. BALARAM, Molecular \\ Biophysics Unit, Indian Institute of Science, Bangalore 560 012, India
}

\section{Synopsis}

The conformation of cyclolinopeptide A [cyclo(Pro-Pro-Phe-Phe-Leu-Ile-Ile-Leu-Val)], a naturally occurring cyclic nonapeptide has been investigated in dimethylsulfoxide solution by 270 $\mathrm{MHz}^{1} \mathrm{H}$-nmr. A complete assignment of all $\mathrm{C}^{\alpha} \mathrm{H}$ and $\mathrm{NH}$ resonances has been accomplished using two-dimensional correlated spectroscopy and nuclear Overhauser effects (NOEs). Analysis of interresidue NOEs and $J_{\mathrm{HNC}^{a} \mathrm{H}}$ values permit construction of a molecular model for the cyclic peptide backbone. The crude model derived from $\mathrm{nmr}$ has been used as a starting point for energy minimization, which yields a refined structure largely compatible with $\mathrm{nmr}$ observations. The major features of the conformation of cyclolinopeptide $A$ are a Type VI $\beta$-turn centered at Pro(1)-Pro(2), with a cis peptide bond between these residues and a $\gamma$-turn $\left(\mathrm{C}_{7}\right.$ structure) centered at Ile(6). Two intramolecular hydrogen bonds Val(9) CO-Phe(3)NH (4 $\rightarrow 1)$ and Leu(5) $\mathrm{CO}-\mathrm{Hle}(7) \mathrm{NH}(3 \rightarrow 1)$ are observed in the low-energy conformation. The limited solvent accessibility observed for the $\mathrm{Val}(9)$ and $\mathrm{Leu}(5) \mathrm{NH}$ groups in the nmr studies are rationalized in terms of steric shielding.

\section{INTRODUCTION}

Cyclolinopeptide A (1) is a cyclic nonapeptide isolated from linseed,,$^{1,2}$ which bears a marked similarity of sequence to the cyclic decapeptide antamanide (2), isolated from the poisonous mushroom Amanita phalloides. ${ }^{3}$ There has been considerable interest in recent years on the conformational properties of cyclic peptides, ${ }^{4-6}$ stimulated by their widespread occurrence as biologically active natural products. ${ }^{7} \mathrm{~A}$ large body of work has focused on the conformational properties of cyclic tri-, tetra-, penta-, and hexapeptides. ${ }^{8}$ Less attention has been paid to the larger cyclic peptides, although the naturally occurring cyclic decapeptides gramicidin $\mathrm{S}^{4,9}$ and antamanide ${ }^{10-14}$ have been the subject of several investigations. Recent studies of larger cyclic peptides ranging in size from octa- to pentadecapeptides ${ }^{15-21}$ are of particular relevance. In most cases the presence of Gly and/or D-residues in addition to L-amino acids facilitates chain reversal and cyclization. Cyclolinopeptide A (1), which has an all-L sequence with particularly bulk side chains, has itself been the subject of conformational investigations by $\mathrm{CD},{ }^{22,23}{ }^{1} \mathrm{H}$ - and ${ }^{13} \mathrm{C}-\mathrm{nmr}$ spectroscopy, ${ }^{24,25}$ and theoretical calculations. ${ }^{26}$ The ion-binding properties of 


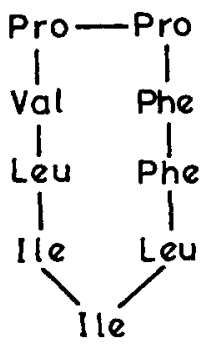

$\stackrel{1}{\sim}$

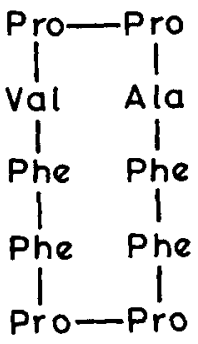

2

1 have also been examined in preliminary fashion. ${ }^{27,28}$ Recently 1 has been shown to inhibit the transport system responsible for uptake of cholate into hepatocytes, thereby exerting a cytoprotective effect, an activity that is also exhibited by antamanide and some synthetic cyclic peptide analogs. ${ }^{29}$ Much of the earlier studies have been based on limited spectral data and the conformational conclusions have been, necessarily, less than definitive. We describe in this report, a detailed $\mathrm{nmr}$ study of 1 in dimethylsulfoxide solutions. Two-dimensional correlated spectroscopy (COSY) ${ }^{30,31}$ and difference nuclear Overhauser methods (NOE), ${ }^{32,33}$ in conjunction with computer modeling and energy minimization, permit the delineation of a predominant solution conformation.

\section{EXPERIMENTAL}

Cyclolinopeptide A (1) was isolated from linseed cake, as described earlier, ${ }^{23}$ and was kindly provided by Dr. S. Rajappa.

\section{NMR STUDIES}

${ }^{1} \mathrm{H}-\mathrm{nmr}$ spectra were recorded on a Bruker WH-270 Fourier transform nmr spectrometer equipped with an Aspect 2000 computer at the Sophisticated Instruments Facility, Indian Institute of Science, Bangalore. All chemical shifts are expressed as $\delta(\mathrm{ppm})$ downfield from internal tetramethylsilane. Two-dimensional (2D) data processing was done on an Aspect 3000 computer. For the COSY spectra 256 FIDs, each of 24 accumulations with a 1-s relaxation delay were collected. Data points of $1 \mathrm{~K}$ were used in the $t_{2}$ domain. Both $t_{1}$ and $t_{2}$ domains were zero filled to give a $2 \mathrm{~K} \times 1 \mathrm{~K}$ data matrix. Unshifted sine-bell window functions were applied prior to Fourier transformation in both domains. Quadrature detection with constant phase of pulses was used. The spectral widths are 4424 and $2212 \mathrm{~Hz}$ in the $t_{2}$ and $t_{1}$ domains, respectively. The spectrum shown in Fig. 2 is symmetrized. In the difference NOE experiments ${ }^{32,33}$ the perturbed and normal spectra recorded sequentially (one on-resonance and one off-resonance) in different parts of the memory ( $8 \mathrm{~K}$ each) were obtained by low-power on-resonance saturation of a peak for $3 \mathrm{~s}$ and by off-resonance shifting of the irradiation frequency, respectively. A relaxation delay of $3 \mathrm{~s}$ was employed between pulses. Data points of $8 \mathrm{~K}$ with 
$3000 \mathrm{~Hz}$ spectral width were used. Five hundred transients were acquired for each experiment. A peptide concentration of $9.6 \mathrm{~m} M$ was employed for both COSY and NOE measurements.

\section{COMPUTER MODELING AND ENERGY MINIMIZATION}

A nonapeptide model was generated using an approximate set of $\phi, \psi$ values obtained from nmr results. All peptide units were fixed in the trans geometry, with the exception of the Pro(1)-Pro(2) bond, which was fixed in the cis geometry. A trial and error method was employed, using modeling through computer graphics, to obtain a reasonably satisfactory set of dihedral angles that permit ring closure. Skeletal Kendrew models were constructed using these dihedral angles and a set of atomic coordinates were obtained as a starting point for further energy minimization, using the method of steepest descent. The standard values for the dimensions of the peptide units (cis and trans) and the various energy functions and constants used are the same as those described earlier. ${ }^{34,35}$ Proline ring dimensions are as reported earlier. ${ }^{36}$ The minimization has been carried out on a model in which all the amino acid side chains, with the exception of the two prolyl residues, have been replaced by methyl groups (L-alanine). This simplification, necessitated by computational limitations, is reasonable since the purpose of the present study is to obtain stereochemically and energetically favorable backbone conformations, which are compatible with $\mathrm{nmr}$ results. All computations were performed on an HP-1000 computer.

\section{RESULTS AND DISCUSSION}

\section{NMR Studies}

Figure 1 shows the $270-\mathrm{MHz}{ }^{1} \mathrm{H}-\mathrm{nmr}$ spectra for 1 in $\left(\mathrm{CD}_{3}\right)_{2} \mathrm{SO}(9.6 \mathrm{mM})$ at two different temperatures. At $293 \mathrm{~K}$, the spectrum is characterized by extremely broad NH resonances (7.4-8.3 $\delta$ ). A selective broadening of several $\mathrm{C}^{\alpha} \mathrm{H}$ resonances is also seen, while the side-chain phenyl and methyl resonances are distinctly sharper. Raising the temperature results in a dramatic sharpening of the resonances by $323 \mathrm{~K}$ and an extremely well-resolved spectrum is obtained at $343 \mathrm{~K}$ [Fig. 1(a)]. A similar broadening of the spectrum was observed even on tenfold dilution of the peptide $(0.96 \mathrm{~m} M)$, suggesting that the increased line widths are not a consequence of aggregation effects. Furthermore, spectra obtained at lower frequencies of $80 \mathrm{MHz}$ (this study) and $100 \mathrm{MHz}^{25}$ showed distinctly sharper $\mathrm{NH}$ resonances. The observation of selective broadening of specific resonances, together with the absence of concentration effects and the line narrowing at lower frequencies, suggest that exchange broadening influences the observed spectrum at $293 \mathrm{~K}$. Chemical exchange between a major conformer and a minor species, present in undetectably small amounts, have indeed been shown to result in selective line broadening in the case of the cyclic tetradepsipeptide AM toxin II. ${ }^{37}$ All subsequent studies on 1 were carried out at $343 \mathrm{~K}$, in the fast-exchange limit, where the spectral parameters are dominated by contributions from major conformations. 

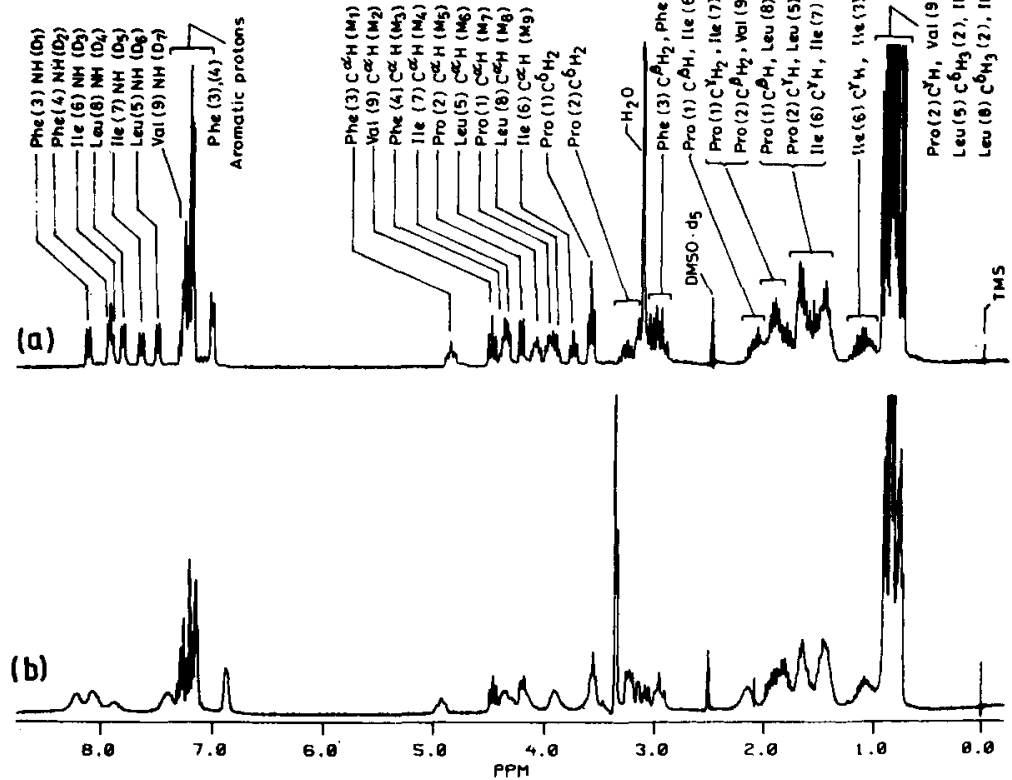

Fig. 1. (270 MHz) spectra ${ }^{1} \mathrm{H}-\mathrm{nmr}$ of cyclolinopeptide 1 in $\left(\mathrm{CD}_{3}\right)_{2} \mathrm{SO}$ at (a) $343 \mathrm{~K}$ and (b) $293 \mathrm{~K}$.

\section{ASSIGNMENTS OF RESONANCES}

The chemical shifts of the $\mathrm{NH}$ and $\mathrm{C}^{\alpha} \mathrm{H}$ resonances are summarized in Table I. Specific assignments of the seven NH resonances (numbered as $D_{n}$, where the subscript $n$ denotes order of appearance from low field) and the nine $C^{\alpha} H$ resonances (labeled as $M_{n}$ ) were made by using the $2 D$ COSY spectrum shown in Fig. 2 and NOEs between $\mathrm{NH}$ and $\mathrm{C}^{\alpha} \mathrm{H}$ protons. Figs. 3-5

TABLE I

NMR Parameters in Cyclolinopeptide $\mathrm{A}\left[\left(\mathrm{CD}_{3}\right)_{2} \mathrm{SO}, 343 \mathrm{~K}\right]$

\begin{tabular}{|c|c|c|c|c|c|}
\hline Residue & $\delta_{\mathrm{C}^{\alpha} \mathrm{H}}$ & $\delta_{\mathrm{NH}}$ & $\begin{array}{c}d \delta / d T \times 10^{3} \\
(\mathrm{ppm} / \mathrm{K})\end{array}$ & $\begin{array}{c}J_{\mathrm{HNC}^{\alpha} \mathrm{H}^{\mathrm{b}}} \\
(\mathrm{Hz})\end{array}$ & $\phi\left({ }^{\circ}\right)^{\mathrm{c}}$ \\
\hline Phe(3) & $4.85\left(\mathrm{M}_{1}\right)$ & $8.110\left(D_{1}\right)$ & 2.8 & $8.7(9.0)$ & $-98,-142$ \\
\hline Phe(4) & $4.38\left(\mathrm{M}_{3}\right)$ & $7.897\left(\mathrm{D}_{2}\right)$ & 6.2 & $5.9(6.0)$ & $35,85,-73,-167$ \\
\hline Leu(5) & $4.09\left(\mathrm{M}_{6}\right)$ & $7.481\left(D_{6}\right)$ & -0.9 & $7.3(6.4)$ & $-84,-156$ \\
\hline Ile(6) & $3.76\left(\mathrm{M}_{9}\right)$ & $7.921\left(\mathrm{D}_{3}\right)$ & 4.1 & $6.9(6.1)$ & $54,66,-81,-159$ \\
\hline Ile(7) & $4.35\left(M_{4}\right)$ & $7.629\left(D_{5}\right)$ & 4.7 & $8.9(8.7)$ & $-99,-140$ \\
\hline Leu(8) & $3.92\left(\mathrm{M}_{\mathrm{B}}\right)$ & $7.794\left(D_{4}\right)$ & 4.7 & $6.9(5.9)$ & $54,66,-81,-159$ \\
\hline Val(9) & $4.48\left(\mathrm{M}_{2}\right)$ & $7.22\left(\mathrm{D}_{7}\right)$ & 2.8 & 9.5 & $-110,-130$ \\
\hline
\end{tabular}

The Pro $\mathrm{C}^{\alpha} \mathrm{H}$ chemical shifts are Pro(1) $3.97\left(\mathrm{M}_{7}\right)$ and Pro(2) $4.22\left(\mathrm{M}_{5}\right)$

${ }^{b}$ Values in parentheses are obtained at $313 \mathrm{~K}$. Errors in $J$ values are $\sim 0.2 \mathrm{~Hz}$. For Val(9) $\mathrm{NH}$ the $J$ value is determined from a difference decoupling experiment and the associated errors are larger, viz., $-0.5 \mathrm{~Hz}$.

$\mathrm{c}_{\phi}$ values obtained using the expression ${ }^{3} J_{\mathrm{HNC}}{ }_{\mathrm{H}}=6.4 \cos ^{2} \theta-1.4 \cos \theta+1.9 \mathrm{~Hz}$, where $\phi=$ $-\theta+60^{\circ}$ and $\theta+60^{\circ}$. 


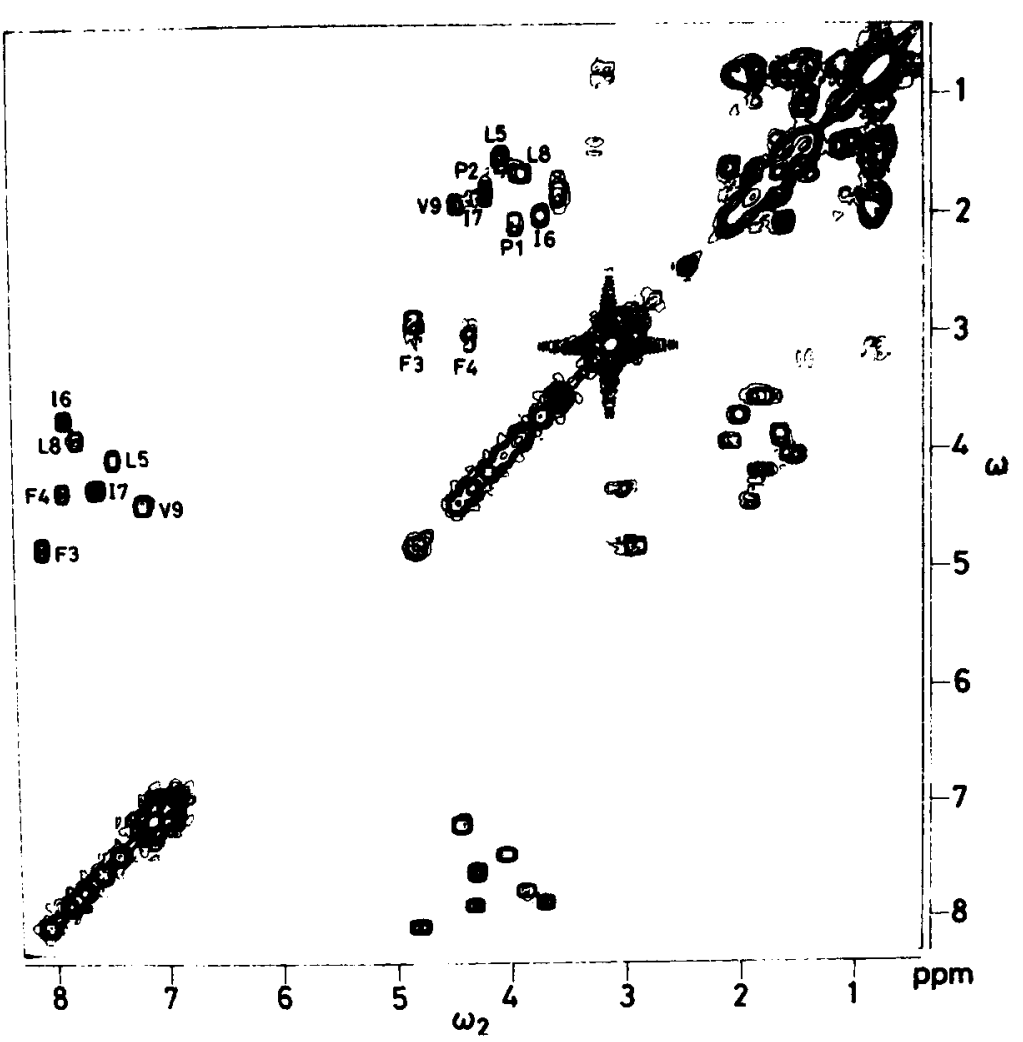

Fig. 2. Two-dimensional COSY spectrum of 1 in $\left(\mathrm{CD}_{3}\right)_{2} \mathrm{SO}$ at $343 \mathrm{~K}$. Assignments are marked using the one-letter code for amino acids (Phe-F, Pro-P, Leu-L, Le-I, Val-V).
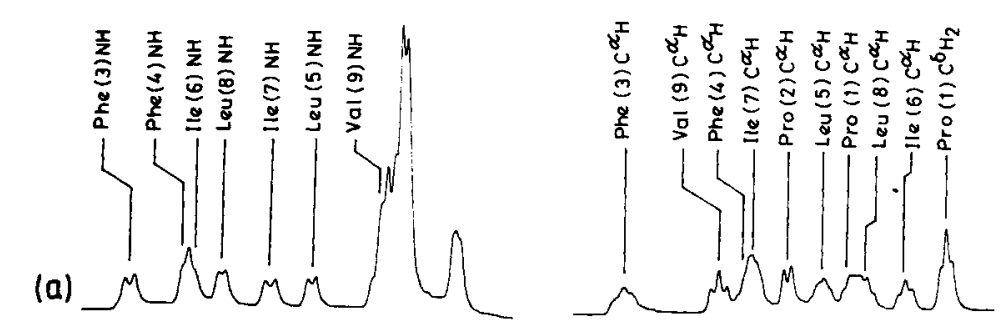

(b)
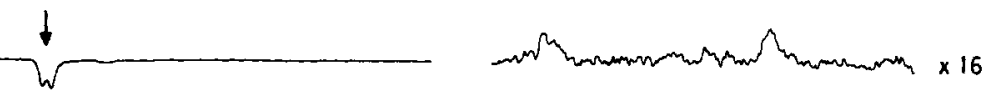

(c)
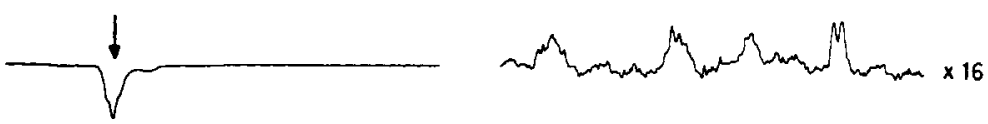

(d)
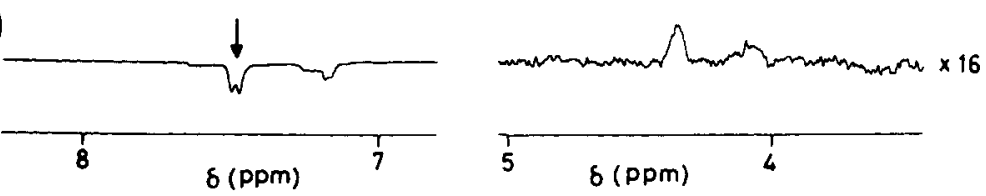

Fig. 3. (a) $\mathrm{C}^{\alpha} \mathrm{H}$ and NH resonances of 1 at $343 \mathrm{~K}$. (b)-(d) Difference NOE spectra obtained by saturating specific NH resonances, indicated by arrows. 


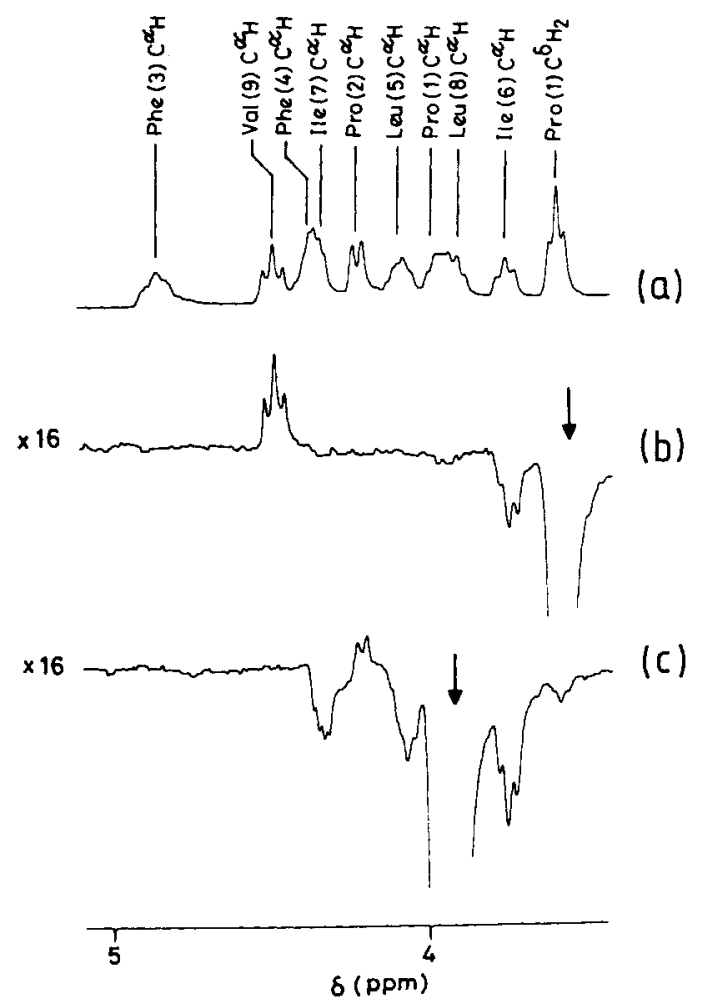

Fig. 4. (a) Partial 270-MHz ${ }^{1} \mathrm{H}-\mathrm{nmr}$ spectrum of $1 \mathrm{in}\left(\mathrm{CD}_{3}\right)_{2} \mathrm{SO}$ at $343 \mathrm{~K}$. Only $\mathrm{C}^{\alpha} \mathrm{H}$ and Pro(1) $\mathrm{C}^{\delta} \mathrm{H}_{2}$ resonances are shown. (b) and (c) Difference NOE spectra obtained by saturation of Pro(1) $\mathrm{C}^{\delta} \mathrm{H}_{2}$ (b) and Pro(1) $\mathrm{C}^{\alpha} \mathrm{H}$ (c) resonances. Note observed NOEs on Val(9) $\mathrm{C}^{\alpha} \mathrm{H}$ (b) and Pro(2) $\mathrm{C}^{\alpha} \mathrm{H}$ (c).

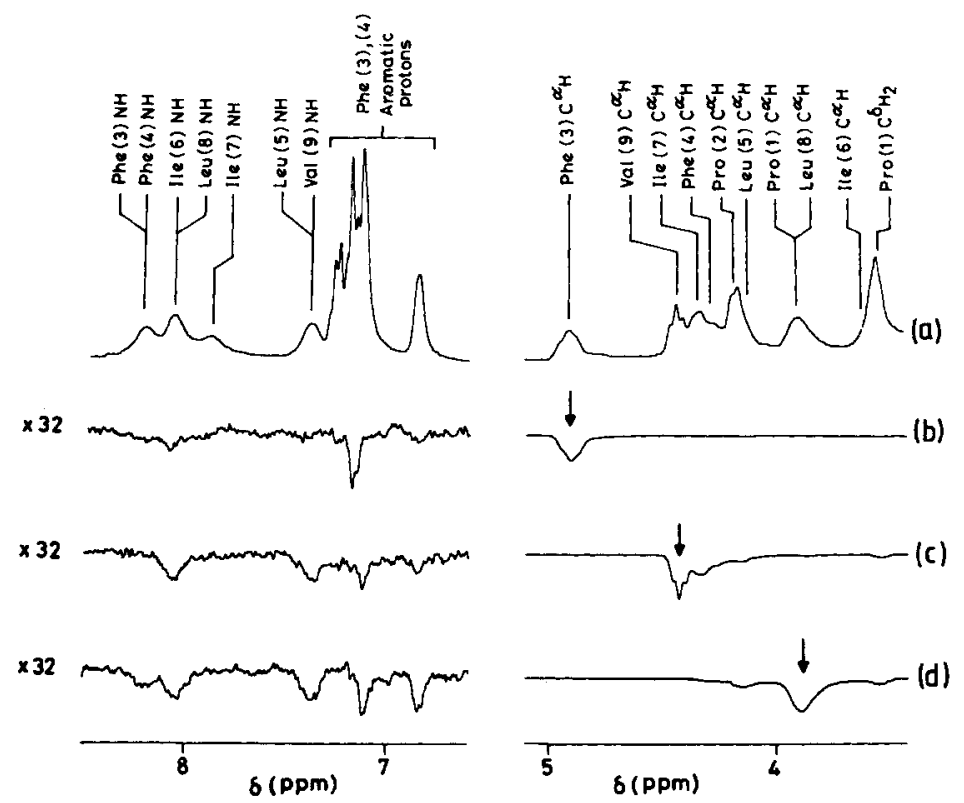

Fig. 5. (a) $\mathrm{C}^{\alpha} \mathrm{H}$ and $\mathrm{NH}$ resonances of 1 in $\left(\mathrm{CD}_{3}\right)_{2} \mathrm{SO}$ at $293 \mathrm{~K}$. (b)-(d) Difference NOE spectra obtained by saturating specific $\mathrm{C}^{\alpha} \mathrm{H}$ resonances, indicated by arrows. Note that all observed NOEs are negative at this temperature. 


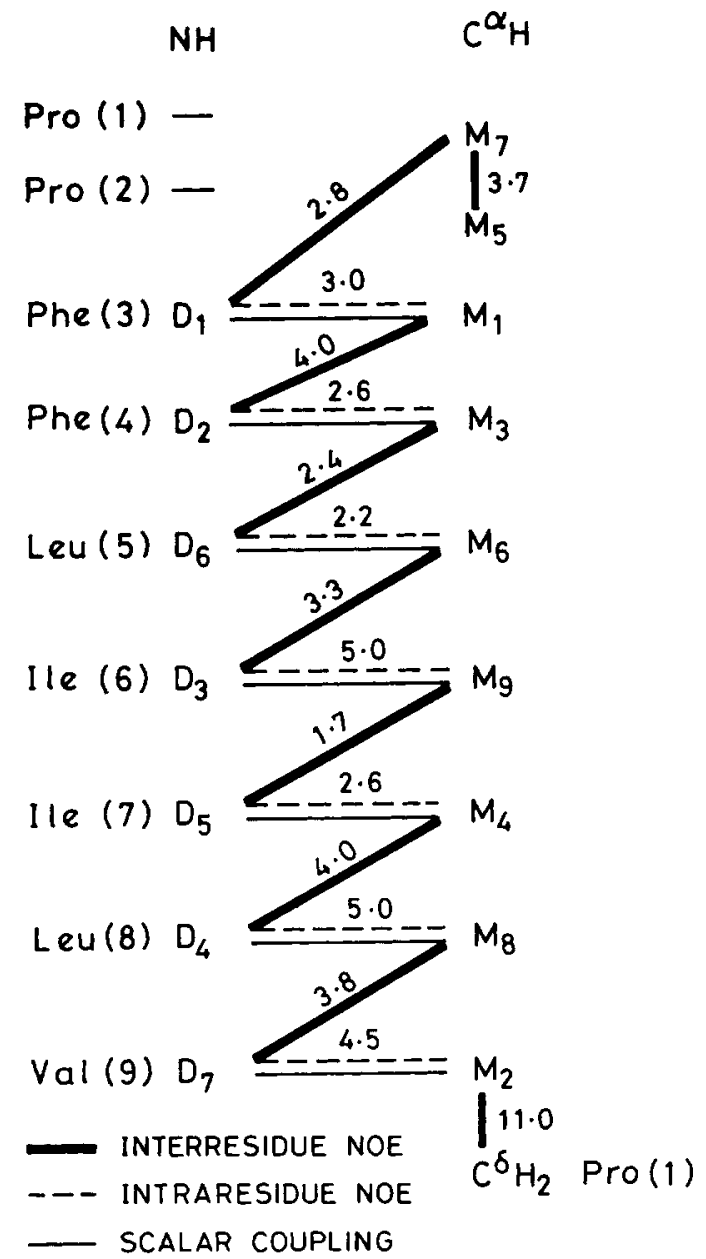

Fig. 6. Schematic representation of sequential resonance assignments obtained from COSY and NOE experiments. NOE magnitudes (\%) are indicated.

show the results of typical NOE experiments, and the relevant magnitudes are indicated in Fig. 6. The individual spin systems corresponding to the various amino acid residues may be readily discerned in the COSY spectrum. The low-field $\mathrm{C}^{\alpha} \mathrm{H}$ resonance at $4.85 \delta\left(\mathrm{M}_{1}\right)$ is easily recognized as due to a Phe residue, in contrast to an earlier study that assigned this signal to an Ile residue. ${ }^{24}$ Indeed, examination of this $\mathrm{C}^{\alpha} \mathrm{H}$ multiplet at high resolution further confirms that this resonance cannot be ascribed to an Ile residue, since the Ile $\mathrm{C}^{\alpha} \mathrm{H}$ signal should necessarily appear as a triplet or a doublet of doublets. Both intra- $\left(\mathrm{C}_{i}^{\alpha} \mathrm{H}-\mathrm{N}_{i} \mathrm{H}\right)$ and interresidue $\left(\mathrm{C}_{i}^{\alpha} \mathrm{H}-\mathrm{N}_{i+1} \mathrm{H}\right)$ NOEs have been detected (Fig. 6) that permit sequential assignments. ${ }^{38}$ The large NOE (11\%) observed between the $C^{\alpha} \mathrm{H}$ resonance $\mathrm{M}_{2}(4.48 \delta)$ and the Pro $\mathrm{C}^{\delta} \mathrm{H}_{2}$ protons (3.56 $\delta$ ) (Fig. 4) permits the unambiguous identification of this signal as the $\mathrm{Val}(9) \mathrm{C}^{\alpha} \mathrm{H}$ resonance. This resonance shows a COSY connectivity to an NH resonance at $7.22 \delta$, which overlaps with the aromatic proton resonances. The chemical shifts and coupling constants characterizing the 
Val(9) NH resonance were obtained by a difference decoupling experiment. Further, the low-field $\mathrm{C}^{\alpha} \mathrm{H}$ resonance $(4.85 \delta$ ) shows NOEs to both the Phe $\mathrm{NH}$ resonances $\left(\mathrm{D}_{1}\right.$ and $\left.\mathrm{D}_{2}\right)$. Of these, $\mathrm{D}_{1}$ is also connected to the Phe $\mathrm{C}^{\alpha} \mathrm{H}$ resonance $\left(M_{1}\right)$ in the COSY spectrum, thus confirming that resonances $D_{1}$ and $M_{1}$ may be assigned to $\mathrm{Phe}(3)$. The two Pro $\mathrm{C}^{\alpha} \mathrm{H}$ resonances appear as a broad doublet $\left(M_{5}\right)$ and a multiplet $\left(M_{7}\right)$. The observation of an NOE between the two $\mathrm{C}^{\alpha} \mathrm{H}$ resonances (Fig. 4) confirms that the Pro(1)-Pro(2) bond exists in the cis conformation. The doublet $\mathrm{C}^{\alpha} \mathrm{H}$ resonance $\left(\mathrm{M}_{5}\right)$ may then be assigned to Pro(2), as earlier studies suggest that X-Pro systems in a cis conformation are often characterized by a doublet $\mathrm{C}^{\alpha} \mathrm{H}$ resonance. ${ }^{11}$ These assignments are further confirmed by an analysis of the interproton NOEs for the Val(9)-Pro(1)-Pro(2)-Phe(3) segment (vide infra). The derivation of the assignments using the inter- and intraresidue NOEs and the intraresidue scalar coupling connectivities are schematically summarized in Figures 6 and 7. The specific assignments made in this study differ from those made earlier ${ }^{24}$ for six out of the seven $\mathrm{NH}$ resonances, the sole exception being the Leu(8) $\mathrm{NH}$ group. A clear identification was also possible in this study.

The spin-spin coupling constants $J_{\mathrm{HNC}{ }^{\circ} \mathrm{H}}$, were determined using resolution-enhanced spectra with high digital resolution $(0.14 \mathrm{~Hz} /$ point $)$. The chemical shift and coupling constants for the various $\mathrm{NH}$ groups are listed in Table I.

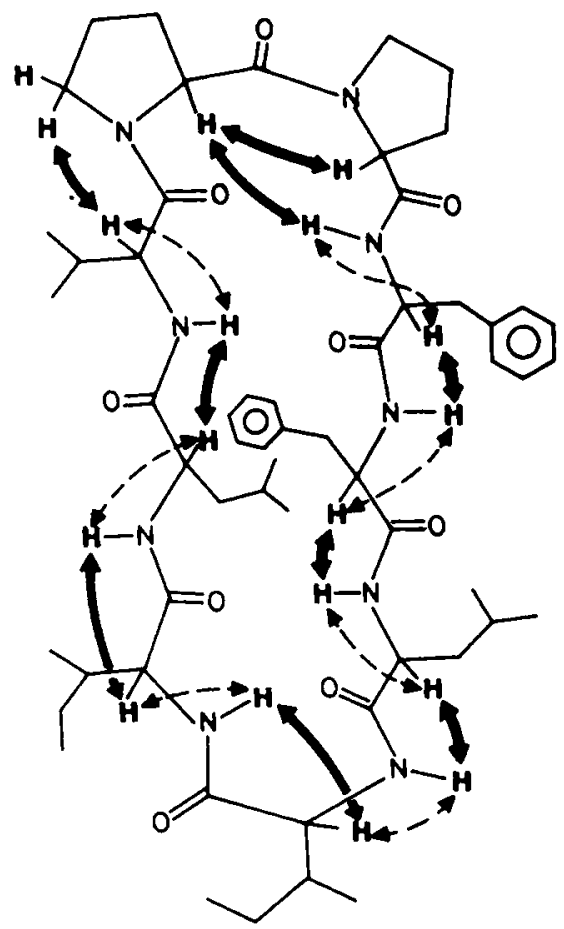

Fig. 7. Structure of 1 with interresidue NOEs (thick arrows) and scalar coupling connectivities (broken arrows) indicated. 


\section{SOLVENT ACCESSIBILITY OF NH GROUPS}

Temperature dependence of $\mathrm{NH}$ chemical shifts were measured in order to probe the accessibility of peptide $\mathrm{NH}$ groups to the hydrogen bond accepting solvent, $\left(\mathrm{CD}_{3}\right)_{2} \mathrm{SO} .{ }^{39}$ Six of the seven $\mathrm{NH}$ groups move upfield with increasing temperature, in a linear fashion, while the Leu(5) $\mathrm{NH}\left(\mathrm{D}_{6}\right)$ moves very slightly to low field. The temperature coefficients $(d \delta / d T)$ estimated by fitting a least squares line to the experimental points are listed in Table I. These values are in reasonable agreement with the results of earlier reports ${ }^{24,27}$ which determined $d \delta / d T$ values for six $\mathrm{NH}$ resonances, with the exception of $\mathrm{D}_{7}$. The $d \delta / d T$ values for the $\mathrm{Phe}(3)$ and $\operatorname{Val}(9) \mathrm{NH}$ groups are clearly characteristic of solvent-shielded NH resonances $(<0.003 \mathrm{ppm} / \mathrm{K}) .{ }^{39}$ The Leu(5) NH resonance has an unusual negative $d \delta / d T$ value, indicative of its shift to lower field with increasing temperature. This $\mathrm{NH}$ may also be classified as solvent inaccessible. The $d \delta / d T$ value for the $\mathrm{Phe}(4) \mathrm{NH}$ resonance $(0.006 \mathrm{ppm} / \mathrm{K})$ is indicative of its solvent-exposed nature. The remaining three $\mathrm{NH}$ resonances -Ile(6), Ile(7), and Leu(8)-exhibit intermediate $d \delta / d T$ values that are indicative of a significant degree of solvent exposure. In a previously published study, slow hydrogen-deuterium exchange rates were observed only for resonances $D_{6}$ and $D_{5}$, now assigned to the Leu(5) and Ile(7) NH groups. ${ }^{24}$ These results do not permit an unambiguous delineation of the solvent-shielded NH groups in the peptide. Further elaboration of the conformational features of the peptide have therefore been derived from NOE studies.

\section{NOE STUDIES}

Figure 5 shows the results of a typical NOE experiment carried out at ambient probe temperature $(\sim 291 \mathrm{~K})$ on 1 . Under these conditions only negative NOEs are observed, suggesting that rotational correlation times are long enough to fulfill the condition $\omega \tau_{c}>1 .^{40}$ The line broadening precludes a detailed structural analysis at $291 \mathrm{~K}$. NOE studies were consequently conducted at $343 \mathrm{~K}$ and representative results are shown in Figs. 3 and 4 . At this temperature all observed NOEs are positive, suggesting that $\omega \tau_{\mathrm{c}} \ll 1$.

Irradiation of specific $\mathrm{NH}$ resonances $\left(\mathrm{D}_{1}-\mathrm{D}_{7}\right)$ yielded both interresidue $\left(\mathrm{C}_{i}^{\alpha} \mathrm{H} \leftrightarrow \mathrm{N}_{i+1} \mathrm{H}\right)$ and intraresidue $\left(\mathrm{C}_{i}^{\alpha} \mathrm{H} \leftrightarrow \mathrm{N}_{i} \mathrm{H}\right)$ NOEs. All the observed NOEs were about $2-5 \%$ in magnitude. For residues Phe(3), Leu(5), and Ile(7) the interresidue NOEs were greater than the intraresidue NOEs, suggesting that the interproton distances $\left(\mathrm{C}_{i}^{\alpha} \mathrm{H} \leftrightarrow \mathrm{N}_{i+1} \mathrm{H}\left(d_{\alpha \mathrm{N}}(i, i+1)\right)\right.$ are less than the distances $\mathrm{C}_{i}^{\alpha} \mathrm{H} \leftrightarrow \mathrm{N}_{i} \mathrm{H}\left(d_{\alpha \mathrm{N}}(i, i)\right)$. For residue $\mathrm{Phe}(4)$ the inter- and intraresidue NOEs are approximately of similar magnitudes. The intraresidue effects are appreciably greater than the interresidue NOEs for $\operatorname{Ile}(6)$ and Leu(8) NH groups, with the difference particularly marked for the former. In the positive NOE region $\left(\omega \tau_{c} \ll 1\right)$ the observation of NOEs is generally diagnostic of interproton distances $<3 \AA .{ }^{41}$ The intraresidue NOE is determined by the distance $d_{\mathrm{aN}}(i, i)$, which is dependent on the dihedral angle $\phi_{i}{ }^{42,43}$ For L-residues the predominant sterically allowed region of the Ramachandran map ${ }^{44,45}$ lies between $\phi \sim 30^{\circ}$ to $-180^{\circ}$. In this region $d_{\alpha N}$ varies from 2.3 to $2.9 \AA$. Thus the observation of an intraresidue NOE is not a particularly good indicator of the value of $\phi$. The interresidue NOE that is 


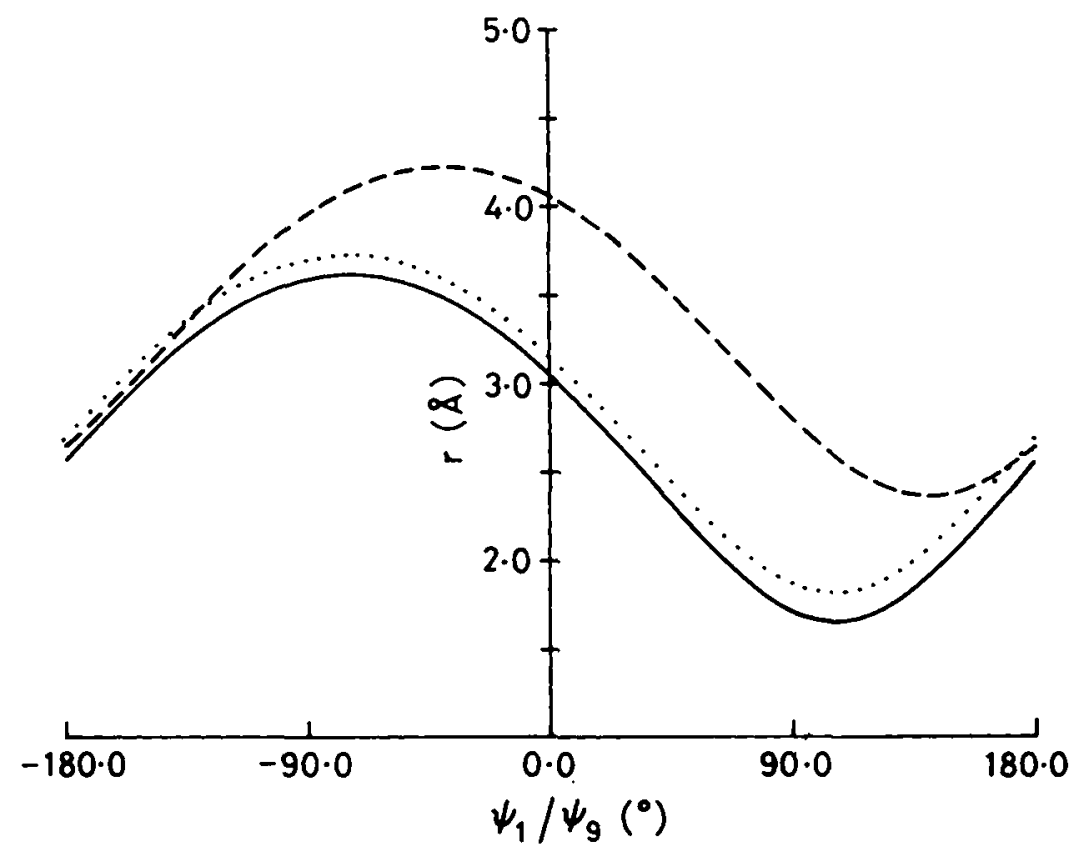

Fig. 8. Variation of interproton distances that are dependent on a single parameter ( ...) Pro(1) $\mathrm{C}^{\alpha} \mathrm{H}$-Pro(2) $\mathrm{C}^{\alpha} \mathrm{H}$ vs $\psi_{\mathrm{Pro}(1)} \cdot(-) \operatorname{Pro}(1) \mathrm{C}^{\delta 1} \mathrm{H}-\mathrm{Val}(9) \mathrm{C}^{\alpha} \mathrm{H}$ vs $\psi_{\mathrm{Val}(9)}$. (---) $\operatorname{Pro(1)} \mathrm{C}^{\delta 2} \mathrm{H}$ $-\mathrm{Val}(9) \mathrm{C}^{\alpha} \mathrm{H}$ vs $\psi_{\mathrm{Val}(9)}$. The standard dimensions have been used for both cis and trans peptide units, ${ }^{45}$ while the Pro residue geometries have been taken from Ref. 36. Pro residues are fixed in the $\mathrm{C}^{\gamma}$-endo conformation with $\phi_{\operatorname{Pro}(1)}=\phi_{\operatorname{Pro}(2)}=-60^{\circ}$.

determined by the distance $d_{\alpha N}(i, i+1)$ is dependent on the dihedral angle $\psi_{i \cdot}{ }^{42,43}$ In the region $\psi_{i} \sim-30^{\circ}$ to $-100^{\circ}, d_{\alpha N}(i, i)>3 \AA$. Short interproton distances $(<3 \AA)$ are expected in the region $\psi \sim 120^{\circ} \pm 60^{\circ}$, which corresponds to an extended conformation. Thus the NOE results are largely consistent with $\psi \sim 120^{\circ}$ for residues Phe(3), Leu(5), and Ile(7).

The Val-Pro-Pro-Phe segment is characterized by three specific NOEs, viz., Val(9) $\mathrm{C}^{\alpha} \mathrm{H} \leftrightarrow \operatorname{Pro}(1) \mathrm{C}^{\delta} \mathrm{H}_{2}$, Pro(1) $\mathrm{C}^{\alpha} \mathrm{H} \leftrightarrow \operatorname{Pro}(2) \mathrm{C}^{\alpha} \mathrm{H}$, and $\operatorname{Pro}(1) \mathrm{C}^{\alpha} \mathrm{H}$ $\leftrightarrow$ Phe(3) NH. These interproton distances are dependent on the dihedral angles $\psi_{\mathrm{Val}(9)}, \psi_{\mathrm{Pro}(1)}$, and $\psi_{\mathrm{Pro}(1)}, \psi_{\mathrm{Pro}(2)}$, respectively. The variations in the interproton distances with the conformational angles are represented in Figs. 8 and 9 , respectively. The observation of these NOEs limits the values of the angles to the regions $\psi_{\mathrm{Val}(9)} \sim 30^{\circ}-180^{\circ}, \psi_{\operatorname{Pro}(1)} \sim 50^{\circ}-180^{\circ}$, and $\psi_{\text {Pro(2) }} \sim 0^{\circ}-140^{\circ}$.These ranges are derived using a $2.6-\AA$ cutoff for observed NOEs and imposing a lower limit of $2.0 \AA$ for short interproton distances. The measured $J_{\mathrm{HNC}{ }_{\mathrm{H}}}$ values were used to provide estimates of the dihedral angle $\phi$ for residues $3-9$, using the angular dependence recently evaluated from an extensive study of bovine pancreati: trypsin inhibitor (BPTI) ${ }^{46}$ The "BPTI based Karplus curve" closely resembles earlier relationships suggested for peptides. ${ }^{47,48}$ The results are summarized in Table 1 . Thus, the $\mathrm{nmr}$ studies permit the construction of a crude backbone model, using parameters within the ranges listed in Table II. 


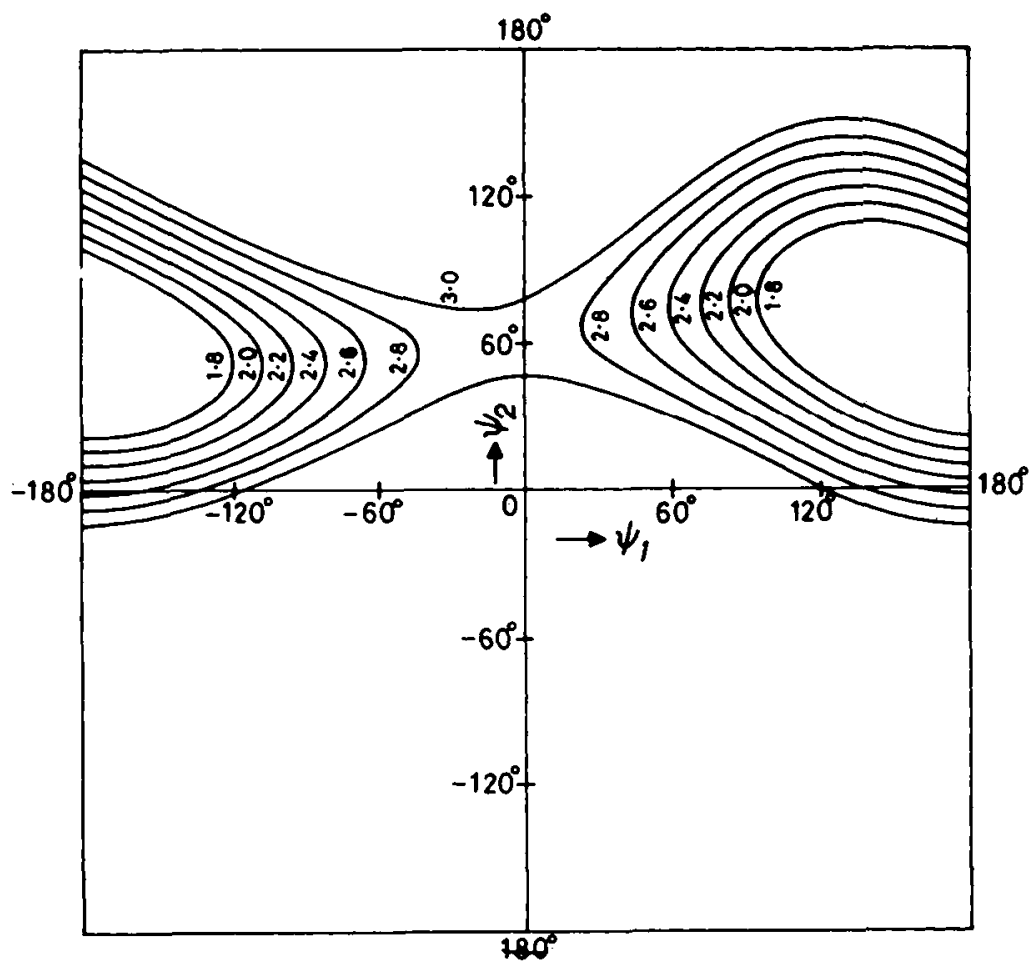

Fig. 9. Contours of constant Phe(3) $\mathrm{NH}-\mathrm{Pro}(1) \mathrm{C}^{\alpha} \mathrm{H}$ interproton distances as a function of $\psi_{\text {Pro(1) }}$ and $\psi_{\text {Pro(2) }}$. Parameters chosen as in Fig. 8.

TABLE II

Conformational Angles ( ${ }^{\circ}$ ) in Cyclolinopeptide A: NMR Estimates and Minimized Model

\begin{tabular}{|c|c|c|c|c|c|c|}
\hline \multirow[b]{2}{*}{ Residue } & \multirow[b]{2}{*}{$\phi(\text { experimental })^{\mathrm{a}}$} & \multirow{2}{*}{$\begin{array}{c}\psi \text { (experimental } \\
\text { range })^{b}\end{array}$} & \multirow{2}{*}{$\begin{array}{c}\text { Diagnastic } \\
\text { NOE }\end{array}$} & \multicolumn{3}{|c|}{ Minimized model $^{c}$} \\
\hline & & & & $\phi$ & $\psi$ & $\tau^{d}$ \\
\hline Pro(1) & -60 & $50-180$ & $\begin{aligned} \mathbf{M}_{6} & \leftrightarrow \mathbf{M}_{7} \\
\mathbf{D}_{1} & \leftrightarrow \mathbf{M}_{7}\end{aligned}$ & -67 & 154 & 109.8 \\
\hline Pro(2) & -60 & $0-140$ & $\mathbf{D}_{1} \leftrightarrow \mathbf{M}_{7}$ & -80 & -1 & 113.3 \\
\hline Phe(3) & -140 & $60-180$ & $\mathbf{D}_{2} \leftrightarrow \mathrm{M}_{1}$ & -125 & 81 & 111.1 \\
\hline Phe(4) & -160 & $60-180$ & $D_{6} \leftrightarrow M_{3}$ & -128 & 138 & 115.2 \\
\hline Leu(5) & -150 & $60-180$ & $D_{3} \leftrightarrow M_{6}$ & -146 & 124 & 109.8 \\
\hline Ile(6) & $\begin{array}{c}-80 \\
(80)\end{array}$ & $\begin{array}{c}50-90 \\
-50--90\end{array}$ & $D_{5} \leftrightarrow M_{9}$ & 79 & -75 & 111.5 \\
\hline Ile(7) & -130 & $60-180$ & $D_{4} \leftrightarrow M_{4}$ & -141 & 52 & 110.9 \\
\hline Leu(8) & -160 & $60-180$ & $\mathrm{D}_{7} \leftrightarrow \mathrm{M}_{8}$ & -122 & 180 & $\cdot 111.2$ \\
\hline Val(9) & -140 & $30-180$ & Pro $\mathrm{C}^{\delta} \mathrm{H}_{2} \leftrightarrow \mathrm{M}_{2}$ & -113 & 155 & 114.8 \\
\hline
\end{tabular}

"For residues 3-9, the $\phi$ values were chosen from those obtained using the BPTI based Karplus curve (see Table I). For Pro(1) and Pro(2), idealized ring geometries with $\phi \sim-60^{\circ}$ were assumed.

$b_{\psi}$ values are given as ranges based on a $2.6 \AA$ cutoff for the observation of NOEs.

'In the final minimization only $\mathrm{C}^{\alpha}$ carbons were used in place of the various gide chains. However, both Pro residues were considered completely, including all ring hydrogen atoms. All the peptide bonds are very nearly planar in the final structure, with $\omega$ values between $-172^{\circ}$ and $-180^{\circ}$ for the trans units and a value of $-1.4^{\circ}$ for the cis Pro-Pro bond.

${ }^{d} \tau$ is the bond angle $N^{a} C^{\prime}$. Satisfactory cyclization depends on this parameter. 


\section{MOLECULAR MODELING AND ENERGY MINIMIZATION}

Several attempts at computer model building were made using $\phi, \psi$ values compatible with $J_{\mathrm{HNC}^{\alpha} \mathrm{H}}$ values and $\mathrm{NOE}$ results. The geometry of the Val-Pro-Pro-Phe segment is well defined by the various interresidue NOEs. Extended conformations $\left(\phi \sim 120^{\circ} \pm 30^{\circ}, \psi \sim 120^{\circ} \pm 30^{\circ}\right)$ were chosen for Phe(4), Leu(5), Ile(7), and Leu(8). For Ile(6), which must occupy the pivotal position in the second chain reversal necessary for cyclization, $\phi$ values corresponding to both the $\gamma$-turn $\left(\phi \sim 70^{\circ}, \psi \sim-70^{\circ}\right)$ and inverse $\gamma$-turn
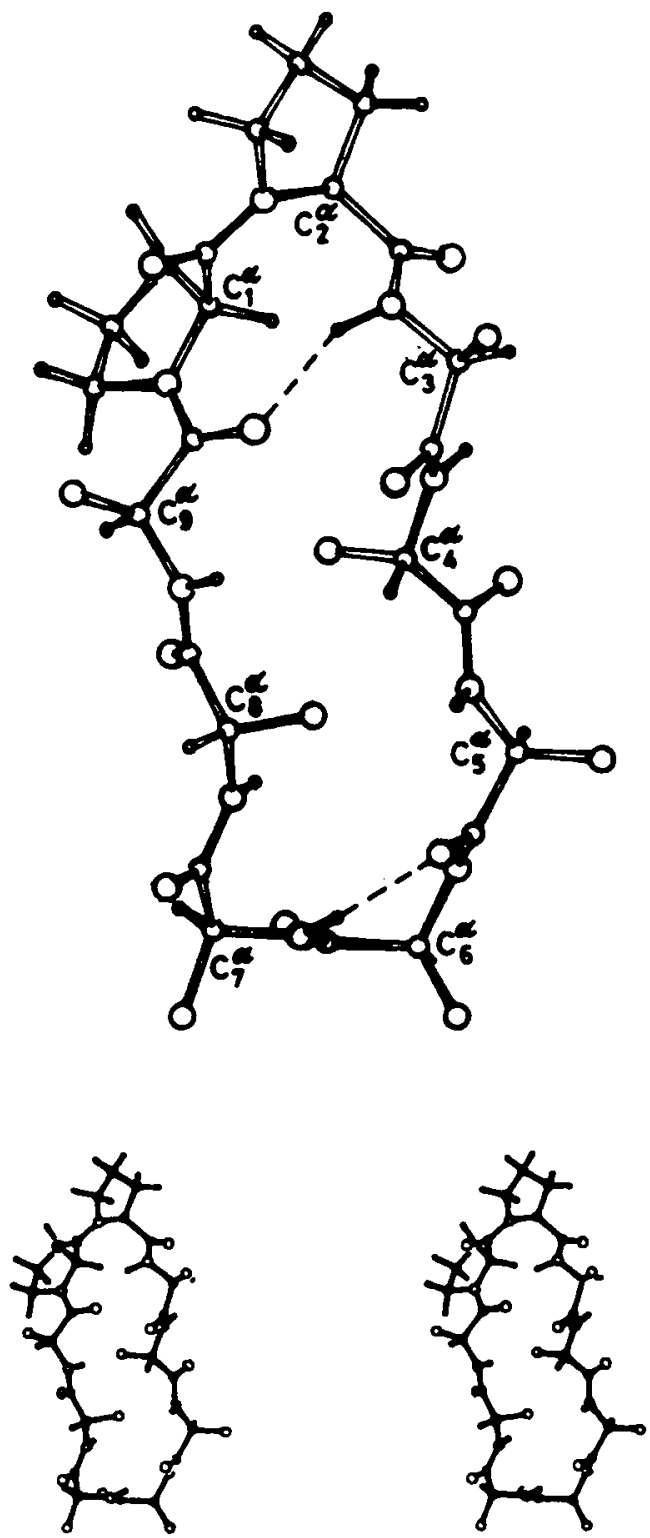

Fig. 10. Perspective view of the low-energy backbone conformation of cyclolinopeptide A. Intramolecular hydrogen bonds (--) are indicated. A stereoview is shown at the bottom. 
TABLE III

Relevant Interproton Distances" in the Minimized Structure of Cyclolinopeptide A

\begin{tabular}{|c|c|c|c|}
\hline Hydrogen atoms & Distance ( $\AA$ ) & Hydrogen atoms & Distance $(\AA)$ \\
\hline $\operatorname{Pro}(1) \mathrm{C}^{\alpha} \mathrm{H}-\operatorname{Pr}(2) \mathrm{C}^{\alpha} \mathrm{H}$ & 2.25 & $\operatorname{Ile}(6) \mathrm{NH}-\operatorname{Ile}(6) \mathrm{C}^{\alpha} \mathrm{H}$ & 2.20 \\
\hline Pro(1) $\mathrm{C}^{\alpha} \mathrm{H}-\mathrm{Phe}(3) \mathrm{NH}$ & 2.42 & Ile(6) ${ }^{\alpha} \mathrm{H}-\operatorname{Ile}(7) \mathrm{NH}$ & $3.60^{\mathrm{b}}$ \\
\hline Phe(3) NH-Phe(3) $C^{\alpha} H$ & 2.92 & $\operatorname{Ile}(7) \mathrm{NH}-\operatorname{Ile}(7) \mathrm{C}^{\alpha} \mathrm{H}$ & 2.90 \\
\hline Phe(3) $\mathrm{C}^{a} \mathrm{H}-\mathrm{Phe}(4) \mathrm{NH}$ & 2.25 & $\operatorname{Ile}(7) \mathrm{C}^{\alpha} \mathrm{H}-\operatorname{Leu}(8) \mathrm{NH}$ & 2.57 \\
\hline Phe(4) NH-Phe(4) $\mathrm{C}^{\alpha} \mathrm{H}$ & 2.95 & $\operatorname{Leu}(8) \mathrm{NH}-\operatorname{Leu}(8) \mathrm{C}^{\alpha} \mathrm{H}$ & 2.97 \\
\hline Phe(4) $C^{\alpha} H-L e u(5) ~ N H$ & 2.18 & $\operatorname{Leu}(8) \mathrm{C}^{\alpha} \mathrm{H}-\mathrm{Val}(9) \mathrm{NH}$ & 2.80 \\
\hline $\operatorname{Leu}(5) \mathrm{NH}-\operatorname{Leu}(5) \mathrm{C}^{a} \mathrm{H}$ & 2.96 & $\operatorname{Val}(9) \mathrm{NH}-\mathrm{Val}(9) \mathrm{C}^{\alpha} \mathrm{H}$ & 2.96 \\
\hline \multirow[t]{2}{*}{$\operatorname{Leu}(5) \mathrm{C}^{\alpha} \mathrm{H}-\operatorname{Ile}(6) \mathrm{NH}$} & 2.13 & $\operatorname{Val}(9) \mathrm{C}^{\alpha} \mathrm{H}-\operatorname{Pro}(1) \mathrm{C}^{\delta} \mathrm{H}_{2}$ & 2.0 \\
\hline & & & 2.9 \\
\hline
\end{tabular}

\footnotetext{
anterproton distances useful for comparison with NOE results are given. Note that a weak Ile(6) $\mathrm{C}^{\alpha} \mathrm{H} \leftrightarrow \operatorname{Ile}(7) \mathrm{NH}$ NOE is observed, although the distance in the minimized model is $>3$ A. A complete correspondence between the theoretical model and observed NOEs may not be obtained due to various factors, including dynamic structural variations in solution, solvation factors, and approximations inherent in energy computations.

${ }^{b}$ See text for a consideration of this large interproton distance.
}

$\left(\phi \sim-70^{\circ}, \psi \sim 70^{\circ}\right)$ conformations ${ }^{49,50}$ are compatible with the observed $J_{\mathrm{HNC} C^{\alpha} \mathrm{H}}$ values (Table I). Choice of the inverse $\gamma$-turn structure leads to difficulties in ring closure. Consequently, the $\gamma$-turn conformation at Ile(6) was used in further modeling. A stereochemically satisfactory structural model obtained by trial and error methods, broadly compatible with nmr data, was used as a starting point for energy minimization. A perspective view of the low-energy conformation obtained is shown in Fig. 10. The conformational parameters are listed in Table II and the relevant interproton distances are summarized in Table III.

\section{FEATURES OF THE CYCLOLINOPEPTIDE A STRUCTURE}

The nonapeptide ring is generated by two chain reversals. A type VI $\beta$-turn ${ }^{4-51}$ with Pro(1)-Pro(2) as the corner residues, having a central cis Pro-Pro peptide bond is stabilized by a $4 \rightarrow 1$ hydrogen bond between the Val(9) $\mathrm{CO}$ and $\mathrm{Phe}(3) \mathrm{NH}$ groups $\left(\mathrm{N}-\mathrm{O} 3.05 \AA \angle \mathrm{H}-\mathrm{N}-\mathrm{O} 20.5^{\circ}\right)$. A $\gamma$-turn $\left(\mathrm{C}_{7}\right.$ structure) is formed at Ile(6) with a $3 \rightarrow 1$ hydrogen bond between Leu(5) $\mathrm{CO}$

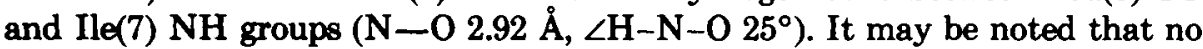
preconditions regarding hydrogen bonding were imposed during the minimization procedure. The $\phi, \psi$ values for $\operatorname{Ile}(6)\left(78^{\circ},-73^{\circ}\right)$ fall into the right-hand lower quadrant of the Ramachandran map, corresponding to a $\gamma$-turn structure. This region indeed corresponds to a low-energy region of $\phi, \psi$ space for an L-residue. ${ }^{45}$ All other residues adopt $\phi, \psi$ values in the left-hand upper quadrant of the $\phi, \psi$ map, which are stereochemically and energetically favored for L-residues. Indeed, the only short contacts noted in this structure are $\mathrm{O}_{2}-\mathrm{H}_{3}^{\alpha} 2.40 \AA, \mathrm{C}_{5}-\mathrm{C}_{6}^{\beta} 3.10 \AA$, and $\mathrm{H}_{9}^{\alpha}-\mathrm{H}_{1}^{\delta 2} 1.85 \AA$. However, these contacts fall within the extreme limits permissible. ${ }^{45}$

The relevant interproton distances calculated for this model (Table III) are fully consistent with the observed NOEs (Fig. 6). No attempt has been made in the present study to quantitatively correlate interproton distances with 
measured NOE magnitudes. ${ }^{52}$ Rather, the observation of several interresidue NOEs has been used to serve as a constraint in the computer modeling studies. All the observed NOEs correspond to proton pairs which are $<3.0 \AA$ apart in the low-energy conformation, with the exception of the Ile(6) $\mathrm{C}^{\alpha} \mathrm{H}$-Ile(7) NH distance (3.6 $\AA$ ). This is, in fact, the smallest NOE detected. It may be noted that the NOE data have been used to facilitate the development of a starting model for refinement by energy minimization and no distance constraints have been used in the minimization procedure. Some features of the model merit comment in relation to the nmr observations. The solvent-shielded nature of the $\mathrm{Phe}(3) \mathrm{NH}$ group is indeed borne out by the $\mathrm{nmr}$ results. These studies also establish that Val(9) $\mathrm{NH}$ and Leu(5) $\mathrm{NH}$ are solvent inaccessible, with the latter exhibiting an anomalous downfield shift with temperature in $\left(\mathrm{CD}_{3}\right)_{2} \mathrm{SO}$ (Table I). Both these $\mathrm{NH}$ groups are not hydrogen bonded in the low-energy conformation shown in Fig. 10. In principle, additional transannular hydrogen bonds (Phe(3) $\mathrm{CO}-\mathrm{Val}(9) \mathrm{NH}$ and Ile(7) $\mathrm{CO}-\operatorname{Leu}(5) \mathrm{NH}$ ) are possible within the cyclic nonapeptide ring. However, neither hydrogen bond is obtained in the minimized conformation. Nevertheless, both Val(9) and Leu(5) NH groups are sterically shielded by their orientation, and may be expected to interact only weakly with the solvent, $\left(\mathrm{CD}_{3}\right)_{2} \mathrm{SO}$. Interestingly, Leu(5) $\mathrm{NH}$ exchanges very slowly in a deuterium exchange experiment. Ile(7) $\mathrm{NH}$ exhibits a rather high $d \delta / d T$ value (Table I), but exchanges slowly in an $\mathrm{H}-\mathrm{D}$ exchange experiment, ${ }^{24}$ suggesting only a moderate degree of shielding from the solvent. This is likely to be a consequence of the rather distorted intramolecular hydrogen bond formed in the $\gamma$-turn. ${ }^{53}$

The structure proposed for cyclolinopeptide $A$ is consistent with much of the reported $\mathrm{nmr}$ data. This conformation is likely to be representative of the major species in $\left(\mathrm{CD}_{3}\right)_{2} \mathrm{SO}$ solutions. The conformational flexibility of the 27-membered ring is clearly reflected in the presence of minor species that contribute to exchange broadening at low temperatures. In the spectrum of the peptide in $\left(\mathrm{CD}_{3}\right)_{2} \mathrm{SO}$ at $293 \mathrm{~K}$ an examination of $\mathrm{C}^{\alpha} \mathrm{H}$ resonances suggests that the broadening is appreciably less for the $\mathrm{Val}(9)$, $\operatorname{Pro}(2)$, and $\mathrm{Phe}(3) \mathrm{C}^{\alpha} \mathrm{H}$ resonances as compared to the other $\mathrm{C}^{\alpha} \mathrm{H}$ resonances. This suggests that the chemical shift difference for $\mathrm{C}^{\alpha} \mathrm{H}$ resonances in the exchanging species is significantly less for the Val(9)-Pro(1)-Pro(2)-Phe(3) segment. Indeed the structure of this segment determined for 1 in solution bears a remarkable similarity to the structure of this segment in the crystal structure of antamanide. The torsion angles for this segment are $\mathrm{Phe}^{4}, \mathrm{Val}^{6}$ antamanide ${ }^{14}$ $\phi_{\text {Val }}=-112^{\circ}, \psi_{\text {Val }}=159^{\circ}, \phi_{\text {Pro }}=-67^{\circ}, \psi_{\text {Pro }}=153^{\circ}, \phi_{\text {Pro }}=-98^{\circ}, \psi_{\text {Pro }}=$ $4^{\circ}, \phi_{\mathrm{Phe}}=-97^{\circ}, \psi_{\mathrm{Phe}}=-35^{\circ}$; natural antamanide ${ }^{13} \phi_{\mathrm{Val}}=-113^{\circ}, \psi_{\mathrm{Val}}=$ $158^{\circ}, \phi_{\text {Pro }}=-64^{\circ}, \psi_{\text {Pro }}=161^{\circ}, \phi_{\text {Pro }}=-80^{\circ}, \psi_{\text {Pro }}=-20^{\circ}, \phi_{\text {Ala }}=-103^{\circ}$, $\psi_{\mathrm{Ala}}=-22^{\circ}$. It does appear that the conformational flexibility associated with the cyclic nonapeptide ring is largely centered about residues $4-8$. The good agreement obtained between the experimentally observed short interproton distances and those derived from the theoretical model support the implicit assumption that the NOE data are primarily representative of a major conformation. It may be noted that conformational averaging in highly, flexible systems can indeed result in nmr-derived virtual "conformations," which do not correspond to any theoretically calculated potential energy minima. ${ }^{54,55}$ However, in the present case the constraints in the cyclic non- 
apeptide ring greatly restrict the range of conformational excursions. Preliminary studies in solvents like chloroform and acetonitrile suggest that conformational equilibria in this system may be solvent dependent, a feature that may rationalize solvent dependence of CD spectra. ${ }^{22,23}$ The structure for 1 determined in this study does not immediately appear to be well suited for ion complexation and indeed there is little evidence for appreciable ionophoric activity. ${ }^{27,28}$ The interannular space is not too crowded with atoms, nor is it too open to accommodate metal ions for coordination. The conformational parameters of the present model are significantly different from those suggested by an early theoretical study. ${ }^{26}$

Subsequent to the submission of this article, a preliminary report of the crystal structure of 1 appeared. ${ }^{56}$ The cis Pro-Pro bond is maintained in the crystalline state. However, five trans annular hydrogen bonds (one $\mathrm{C}_{7}$, two $\mathrm{C}_{10}$, one $\mathrm{C}_{13}$, and one $\mathrm{C}_{17}$ hydrogen-bonded ring) are observed in the crystal structure, in contrast to the present $\mathrm{nmr}$ study where two hydrogen bonds are clearly supported, with a third $\mathrm{NH}$ group largely inaccessible to solvent. Although the proposed solution conformation satisfies a limited set of NOE constraints, the possibility of alternative conformations, which are compatible with nmr data, cannot be excluded. Clearly, a more detailed comparison of the proposed solution and solid state conformations must await further details of the crystal structure. A more detailed exploration of conformational space and the possible existence of dynamic solution equilibria as noted recently for the related peptide antamanide ${ }^{57}$ also merits further consideration.

We are grateful to Dr. S. Rajappa for providing a sample of cyclolinopeptide A. This research was supported by a grant from the Department of Science and Technology, Government of India.

\section{References}

1. Kaufmann, H. P. \& Tobschirbel, A. (1959) Chem. Ber. 92, 2805-2809.

2. Prox, A. \& Weygand, F. (1967) in Peptides: Proceedings of the VIII European Peptide Symposium, Beyerman, H. C., van de Linde, A., Linde, A. \& Van den Brink, M., Eds., NorthHolland, Amsterdam, pp. 158-172.

3. Wieland, Th. (1972) in Chemistry and Biology of Peptides, Meienhofer, J., Ed., Ann Arbor Science Publishers, Ann Arbor, MI, pp. 377-396, and references cited therein.

4. Ovchinnikov, Yu. A. \& Ivanov, V. T. (1982) in Proteins, Vol. 5, Neurath, H. \& Hill, R. L., Eds., Academic Press, New York, pp. 307-642.

5. Karle, I. L. (1981) in The Peptides, Vol. IV, Gross, E. \& Meienhofer, J., Eds., Academic Press, New York, pp. 1-53.

6. Kessler, H. (1982) Angew. Chem. Int. Ed. Engl. 21, 512-523.

7. Ovchinnikov, Yu. A., Ivanov, V. T. \& Shkrob, A. M. (1974) Membrane Active Complexones, Elsevier Scientific, Amsterdam.

8. Ramakrishnan, C., Paul, P. K. C. \& Ramnarayan, C. (1985) J. Biosci. 8, 239-251.

9. Hull, S. E., Karlson, R., Main, P., Woolfson, M. M. \& Dodson, E. J. (1978) Nature (London) 275, 206-207.

10. Tonelli, A. E., Patel, D. J., Goodman, M., Naider, F., Faulstich, H. \& Wieland, Th. (1971) Biochemistry 10, 3211-3216.

11. Patel, D. J. (1973) Biochemistry 12, 667-676.

12. Ovchinnikov, Yu. A. \& Ivanov, V. T. (1975) Tetrahedron 31, 2177-2209.

13. Karle, I. L., Wieland, T., Schermer, D. \& Ottenheym, H. C. J. (1979) Proc. Natl. Acad. Sci. USA 76, 1532-1536.

14. Karle, I. L. (1977) J. Am. Chem. Soc. 99, 5152-5157.

15. Degelaen, J. P., Pham, P. \& Blout, E. R. (1984) J. Am. Chem. Soc. 106, 4882-4890.

16. Cook, W. J., Einspahr, H., Trapane, T. L., Urry, D. W. \& Bugg, C. E. (1980) J. Am. Chem. Soc. 102, 5502-5505. 
17. Kopple, K. D., Parameswaran, K. N. \& Yonan, J. P. (1984) J. Am. Chem. Soc. 106, 7212-7217.

18. Kopple, K. D. \& Go, A. (1977) J. Am. Chem. Soc. 99, 7698-7704.

19. Narutis, V. P. \& Kopple, K. D. (1983) Biochemistry 22, 6233-6239.

20. Kessler, H., Loosli, H. F. \& Oschkinat, H. (1985) Helv. Chim. Acta. 68, 661-681.

21. Loosli, H. F., Kessler, H., Oschkinat, H., Weber, H. P., Petcher, T. J. \& Widmer, A. (1985)

Helv. Chim. Acta. 68, 682-704.

22. Naider, F., Benedetti, E. \& Goodman, M. (1971) Proc. Natl. Acad. Sci. USA, 68, 1195-1198.

23. Balasubramanian, D., Chopra, P., Ardeshir, F. \& Rajappa, S. (1976) FEBS Lett. 65, 69-72.

24. Brewster, A. I. \& Bovey, F. A. (1971) Proc. Natl. Acad. Sci. USA 68, 1199-1202.

25. Siemion, I. Z., Klis, W. A., Sucharda-Sobczyk, A. \& Obermeier, R. (1977) Roczniki Chem. 51, 1489-1498.

26. Tonelli, A. E. (1971) Proc. Natl. Acad. Sci. USA 68, 1203-1207.

27. Klis, W. A., Obermaier, R., Siemion, I. Z., Sucharda Sobczyk, A. \& Gatner, K. (1977) Roczniki Chem. 51, 1499-1509.

28. Chatterji, D., Sankaram, M. B. \& Balasubramanian, D. (1987) J. Biosci. 11, 473-484.

29. Kessler, H., Klein, M., Müller, A., Wagner, K., Bats, J. W., Ziegler, K. \& Frimmer, M. (1986) Angew. Chem. Int. Ed. Engl. 25, 997-999.

30. Aue, W. P., Bartholdi, E. \& Ernst, R. R. (1976) J. Chem. Phys. 64, 2229-2246.

31. Wider, G., Macura, S., Kumar, A., Ernst, R. R. \& Wüthrich, K. (1984) J. Magn. Res. 56, $207-234$.

32. Sanders, J. K. M. \& Mersh, J. D. (1982) Progr. NMR Spectros. 15, 353-400.

33. Rao, B. N. N., Kumar, A., Balaram, H., Ravi, A. \& Balaram, P. (1983) J. Am. Chem. Soc. 105, 7423-7428.

34. Paul, P. K. C. \& Ramakrishnan, C. (1985) J. Biomol. Struct. Dynam. 2, 879-898.

35. Paul, P. K. C. \& Ramakrishnan, C. (1987) Int. J. Peptide Protein Res. 29, 433-454.

36. Balaji, V. N. (1980) Ph.D. thesis, Indian Institute of Science, Bangalore, India.

37. Higashijima, T., Inubushi, T., Ueno, T. \& Miyazawa, T. (1979) FEBS Lett. 105, 337-340.

38. Billeter, M., Braun, W. \& Wüthrich, K. (1982) J. Mol. Biol. 155, 321-346.

39. Wüthrich, K. (1976) NMR in Biological Research: Peptides and Proteins, North-Holland, Amsterdam.

40. Balaram, P., Bothner-By, A. A. \& Dadok, J. (1972) J. Am. Chem. Soc. 95, 4015-4017.

41. Bothner-By, A. A. (1979) in Magnetic Resonance in Biology, Shulman, R. G., Ed., Academic Press, New York, pp. 177-219.

42. Shenderovich, M. D., Nikiforovich, G. V. \& Chipens, G. I. (1984) J. Magn. Res. 59, 1-12.

43. Wüthrich, K., Billeter, M. \& Braun, W. (1984) J. Mol. Biol. 180, 715-740.

44. Ramachandran, G. N., Ramakrishnan, C. \& Sasisekharan, V. (1963) J. Mol. Biol. 7, 95-99.

45. Ramachandran, G. N. \& Sasisekharan, V. (1968) Adv. Protein Chem. 23, 283-438.

46. Pardi, A., Billeter, M. \& Wüthrich, K. (1984) J. Mol. Biol. 180, 741-751.

47. Ramachandran, G. N., Chandrasekaran, R. \& Kopple, K. D. (1971) Biopolymers 10, 2113-2131.

48. DeMarco, A., Llinas, M. \& Wüthrich, K. (1978) Biopolymers 17, 637-650.

49. Smith, J. A. \& Pease, L. G. (1980) CRC Crit. Rev. Biochem. 8, 315-399.

50. Rose, G. D., Gierasch, L. M. \& Smith J. A. (1985) Adv. Protein Chem. 37, 1-109.

51. Richardson, J. S. (1981) Adv. Protein Chem. 34, 167-339.

52. Bruch, M. D., Noggle, J. H. \& Gierasch, L. M. (1985) J. Am. Chem. Soc. 107, 1400-1407.

53. Baker, E. N. \& Hubbard, R. E. (1984) Prog. Biophys. Mol. Biol. 44, 97-179.

54. Cumming, D. A. \& Carver, J. P. (1987) Biochemistry 26, 6664-6676.

55. Jardetzky, O. (1980) Biochim. Biophys. Acta 621, 227-232.

56. Di Blasio, B., Benedetti, E., Pavone, V., Pedone, C. \& Goodman, M. (1987) Biopolymers 26, 2099-2101.

57. Kessler, H., Griesinger, C., Lautz, J., Muller, A., van Gunsteren, W. F. \& Berendsen, H. J. C. (1988) J. Am. Chem. Soc. 110, 3393-3398.

Received January 20, 1988

Accepted June 17, 1988 